\title{
S27 - Rasgos de personalidad y éxito académico en estudiantes de Medicina en Guatemala
}

\author{
Zinzi Ríos-García ${ }^{1}$, Rony Ríos-Guzmán², Raúl Argueta ${ }^{2}$ \\ ${ }^{1}$ Instituto Guatemalteco de Seguridad Social \\ ${ }^{2}$ Facultad de Ciencias Médicas, Universidad de San Carlos de Guatemala
}

*Autor al que se dirige la correspondencia: rios.rony@usac.edu.gt

\section{Resumen}

$\mathrm{E}$ 1 rendimiento académico es explicado por la combinación de diversos factores: institucionales, personales y sociales. Indagando entre los factores personales, se realizó un estudio transversal buscando asociación entre los rasgos de personalidad, detectados mediante el Inventario Multifásico de la Personalidad de Minnesota (MMPI), con el éxito académico en estudiantes de primer ingreso de la Facultad de Ciencias Médicas de la USAC cohorte $2010(\mathrm{n}=433)$. La muestra se dividió en dos grupos: de éxito $(\mathrm{n}=188)$ y de no éxito $(\mathrm{n}=245)$ y se relacionaron las10 escalas clínicas o rasgos de personalidad con el éxito académico definido como la aprobación de las ocho unidades didácticas de primer año de la carrera. Los resultados demostraron que existe asociación entre el rasgo desviación psicopática y el éxito académico (OR $1.87 \mathrm{p}=.040)$. La investigación evidenció además que solo el $29.8 \%$ de los estudiantes presentó un perfil de personalidad normal y el 36\% de la muestra tenía elevados dos o más rasgos patológicos de personalidad. Se concluye que el rasgo de personalidad, desviación psicopática, es el único que se asoció a éxito académico en estudiantes de primer ingreso de Medicina.

Palabras claves: Rasgos de personalidad, MMPI, desviación psicopática

\section{Abstract}

A cademic performance is explained by the combination of several factors: institutional, social and personal. Inquiring between personal factors a transversal study was conducted to analyze the possibility of an existing correlation between a student's personality traits, found by the Minnesota Multiphasic Personality Inventory (MMPI), and his/her academic success. The study was carried out with a 433 freshmen-student sample from the Medicine School of the University of San Carlos of Guatemala, Class of $2010(n=433)$. The sample was divided into two groups: successful students $(n=188)$ and not successful students $(n=245)$. The ten clinical scales or personality traits were analyzed along with the students' academic success, which was defined as the approval of the eight didactic units that are part of the career's first-year curriculum. The results showed that there is a correlation between the Psychopathic Deviate $(\mathrm{Pd})$ trait and the students' academic success (OR $1.87 \mathrm{p}=.040)$. The research results also indicated that only $29.8 \%$ of the students presented a normal personality profile and $36 \%$ of the sample had two or more high pathological personality traits. It is been concluded that personality trait, psychopathic deviation, is the only one associated with academic success in freshmen-student of Medicine School.

Keywords: Academic performance, MMPI, psychopathic deviation, freshmen medicine student 